\title{
Market economics in Russian research
}

\author{
Russian research institutes are being compelled to live by their wits, assembling annual budgets from a variety of \\ sources and attracting young people only if they can pay them enough.
}

\begin{abstract}
Moscow. Everything has changed and everything is the same. That is the first impression of Moscow after the long interval of a year. And the evidence of permanence is the more conspicuous. The Kremlin is still there, of course. So is the sprinkling of gold-domed churches, while the White House, the parliament building attacked by government tanks just nine months ago, has been patched up at unwonted speed. The people in the streets are less drably dressed than a year ago. Signs of the mafia supposed to have a stranglehold on emergent Russian business are not much in evidence. That is the good news.
\end{abstract}

The signs of change are mostly superficial. Hotels and many shops now denominate the prices of what they have to sell in US dollars, but then prominently display a notice proclaiming "RATE $=2100$ " (where the number changes from one day to the next) so that customers can calculate what they must pay in rubles, theoretically the only legal tender now. This is a neat accommodation of inflation, now between 5 and 7 per cent a month. (The dollar rate reached 2,000 last week, six months ahead of January's prediction for the end of the year.)

But the urban road network is disintegrating faster than it can be repaired. In several centre-city streets, potholes must account for half the surface area. On some streets, the surface has been removed in preparation for repair, with the result that heavy iron manhole covers project up to 10 $\mathrm{cm}$ above the driving surface, making simple journeys resemble a giant chicane. Some blame the damage on last October's visitation of tanks, others the sheer weight of traffic. Either is a sufficient explanation.

Meanwhile, beneath the surface, Russia's traditionally rich literary life is fast being eroded. Throughout the Soviet period, the country was amply endowed with monthly literary magazines, Novy Mir for example, which were a good read even in Stalin's time and which, with glasnost in 1986, published previously forbidden texts. Between then and the end of the decade, these magazines were eagerly and widely read and their contents endlessly discussed. But no longer. With the arrival of 'the market', they have become unaffordably expensive. That is one problem. The other is that people no longer have the time to read them. The old habit of curling up in the corner of the laboratory with that month's copy of Novy Mir is no longer acceptable.

Science is in much the same case, but for different reasons. At half a dozen institutes last week, the chief anxiety was the recruitment of able young people. The old routine of assigning able students to institutes in the last one or two years of their first degree course, in the expectation that a well performed candidate's $(\mathrm{PhD})$ course would be followed by permanent employment, has too often been frustrated by young people's preference for better pay.

Pay now depends on an institute's success in recruiting funds from outside the usual channels, the Russian Academy of Sciences in particular. At most research institutes, the academy's share of the budget is down to 30 per cent. Other sources of funds are the science ministry, other government ministries (the Ministry of Atomic Energy, for example), the Soros Funds and the Russian National Research Foundation. Institutes able to make scientific instruments for collaborators abroad do so with a will.

The principle that research institutes must play the market to remain healthy seems well established. The importance, and thus the influence, of the academy is correspondingly reduced. But many institute directors find the need to scrabble around for funds distasteful, even demeaning. Theirs are the institutes that languish.

In the circumstances, it is remarkable that so much enthusiasm abounds. Take, for example, the complex of four research institutes at Troitsk, some $40 \mathrm{~km}$ south of Moscow. (If Novosbirsk in Siberia is a "science city' and Pushchino, further south in Moscow Region, is a 'science town', Troitsk is a 'science village' and may soon be a 'science suburb'.) The Institute of Terrestrial Magnetism and the Ionosphere, or IZMIRAN (one of the four at Troitsk), began life in 1940 as an ionospheric laboratory, which in the 1960 s became a general solar-terrestrial laboratory.

In the early 1970 s, it made an international reputation by injecting beams of charged particles into the Earth's magnetic field from rockets and spacecraft, creating artificial aurorae incidentally to the study of the motion of charged particles in the Earth's magnetic field. Now it has at least one instrument on most Soviet and many international interplanetary spacecraft. Its latest boast is a satellite (KORONAS C) designed to measure X-ray emission from the Sun, from $30 \mathrm{~nm}$ (just beyond the ultraviolet) to the $\gamma$-ray region. It has been the prime mover in the design of an international project in which the ionospheric effects of electron and Xe-ion beams from one satellite are measured at another, whose distance from the source can be varied from a few metres to a few kilometres.

By Russian standards, all this is accomplished economically, by no more than 350 established scientists. Apart from the spacecraft work, there are data to collect from all over Russia, a nonmagnetic ship (a sailing vessel) and a nonmagnetic aircraft to keep in service and instruments to manufacture for all and sundry. The job is done with considerable élan; the snag is that there are too few research students, perhaps because the mean salary is only 100,000 rubles a month, and the average age in the laboratory in what is really a young person's game is 54 .

In the Russian tradition, the laboratory also holds some daring views not shared elsewhere. It believes, for example, that there are regional disturbances of the Earth's geomagnetic field up to two days ahead of major earthquakes and that people are sensitive to magnetic storms, which are said to predispose them to heart attacks. It has already installed magnetometers at three Moscow clinics in the hope that prophylactic strategies can be worked out. The director of IZMIRAN, Professor V. N. Oraevsky, claims epidemiological evidence based on the coincidence of cardiac trouble with the onset of magnetic storms. He promised last week to write with further details.

None of that detracts from the quality of the institute's work, but rather is a measure of how Russian science still suffers from the traditions of self-sufficiency. (Isolation is still fearfully reinforced by the continuing and despairing shortage of journals from elsewhere.) Daring ideas can hang in the air for years on end, untested by the international community. There is also ample evidence that much excellent work is effectively denied international recognition by publication in Russian journals which, even when in English, circulate poorly and slowly elsewhere in the world and, when in Russian, are translated at a snail's pace.

Despite the growing influence of 'the market' on research affairs, it is plain that Russian science is not yet fully alive to the need to market its achievements by the now-standard routes of rigorous peer review followed by modest advocacy of their importance on the international scene, at meetings for example. The belief persists that all publications are equal, equipotent pebbles on the beach of discovery. When last was that the case?

John Maddox 